\title{
Floor Management Systems in an Organic Apple Orchard Affect Fruit Quality and Storage Life
}

\author{
Ibrahim I. Tahir ${ }^{1}$ \\ Department of Plant Breeding, Swedish University of Agricultural Sciences, \\ P.O. Box 101, 23053 Alnarp, Sweden
}

Sven-Erik Svensson and David Hansson

Department of Biosystems and Technology, Swedish University of Agricultural Sciences, P.O. 103, 23053 Alnarp, Sweden

Additional index words. Malus $\times$ domestica Borkh, living mulch, sandwich system, acetic acid, mechanical weed control

\begin{abstract}
In an organic apple orchard, standard mechanical cultivation was compared with four different orchard floor management systems (OFMS): acetic acid (V), living mulch (L), a sandwich system during the growing season (SSS), and a sandwich system during the whole year (SSW). The effects of these OFMS on weed management, soil conditions, tree growth, tree yield, fruit quality, and fruit storage potential in a cool climate were evaluated. Acetic acid treatment showed good weed suppression without any amendatory effect on soil conditions, fruit quality, or tree performance. The $L$ and SSS systems increased soil respiration, decreased tree vigor, and improved fruit quality, but had no sufficient influence on weed competition and thus decreased fruit yield. Only SSW gave better weed control, higher soil respiration, and acceptable tree growth with no yield reduction. Fruit from this system also showed better quality at harvest than fruit from other OFMS and maintained this good quality during storage. A 6-week weed-free period from late May to mid-July gave the highest apple yield in two OFMS (SSW and V).
\end{abstract}

Apple trees are relatively poor competitors with other vegetation because of their low root density per unit of soil, 1 to $10 \mathrm{~cm}$ root per $\mathrm{cm}^{3}$ compared with $10^{3} \mathrm{~cm}$ per $\mathrm{cm}^{3}$ for grasses (Neilsen and Neilsen, 2003). Therefore, high tree productivity depends on low weed competition (Granatstein, 2003; Weibel and Häseli, 2003). In organic apple orchards, floor vegetative cover can be used to improve soil fertility and moisture retention, control soil erosion, increase yield, and develop fruit quality and storage potential, as well as reducing weed competition (Granatstein and Mullinix, 2008; Stefanelli et al., 2009; Zoppolo et al., 2011).

Herbicides are recognized as being a highly effective and relatively inexpensive method for limiting weed competition (Merwin, 2003). However, use of herbicides is very restricted in integrated apple production and they cannot be used in organic orchards as a result of potential adverse effects on the environment, human health, soil microbial activities, and groundwater quality (Atucha et al., 2011; Glover et al., 1999; Merwin et al., 1995).

Tillage within the tree row is a widely used weed control strategy in organic

\footnotetext{
Received for publication 2 Oct. 2014. Accepted for publication 9 Dec. 2014.

Financial support for this study was received from SLU EkoForsk, Partnership Alnarp, and the Program for growth in Swedish horticulture, all at the Swedish University of Agricultural Sciences.

${ }^{1}$ To whom reprint requests should be addressed; e-mail ibrahim.tahir@slu.se.
}

orchards. New equipment for weed control, which permits tillage between adjacent tree trunks, improves tree vegetative growth efficiency (TerAvest et al., 2010). However, tillage can have negative effects on the growth of young trees (Hogue and Neilsen, 1987) and on soil quality (Hoagland et al., 2008). It also increases nitrogen leaching from the root zone (Weidenfeld et al., 1999), impedes internal water drainage (Merwin and Stiles, 1994), disrupts surface roots (Cockroft and Wallbrink, 1996), and lowers soil cation exchange capacity and soil organic matter content (Wooldridge and Harris, 1991). To avoid these negative impacts, mechanical tillage should be replaced with new floor management systems that are productive under the constraints of organic fruit growing (Delate et al., 2008).

Acetic acid (vinegar) has been shown to be effective as a non-selective herbicide in controlling some weeds (Johnson et al., 2004). It is used as weed killer in organic orchards in the United States and it is authorized in several European countries such as Belgium, Denmark, France, Sweden, and the United Kingdom, where concentrations of up to $240 \mathrm{~g} \cdot \mathrm{L}^{-1}$ are used (Delate et al., 2005; SANCO, 2013). However, acetic acid may show poor suppression at low doses, damage low-hanging leaves on apple trees, and decrease soil pH (Markhart et al., 2005).

Although different natural and artificial mulches (such as legume biomass, wood chips, aluminum, bark, propylene) suppress weeds, maintain soil moisture, affect soil temperature, increase organic matter, and enhance soil microbial activities, their use is still restricted because they are expensive and labor-intensive (Sanchez et al., 2003; Tahir et al., 2005; Yao et al., 2005). They may also increase the populations of rodents and other pests (Granatstein and Mullinix, 2008; Merwin et al., 1999).

Establishment of one or more crops in the tree row (living mulch) to prevent weed competition can produce conflicting effects. In some studies it improved soil fertility and water-holding capacity (Merwin et al., 1994), but in others, it decreased root and shoot growth (Atucha et al., 2013; Merwin and Stiles, 1994), delayed fruit maturity, and reduced yield as a result of competition with the fruit trees (Goh and Ridgen, 1995; Marsh et al., 1996).

The "sandwich" system has been developed in Switzerland as a new method of living mulch combined with modified tillage. Annual or perennial crops are sown in a narrow strip (40 to $50 \mathrm{~cm}$ wide) within the tree row, whereas the soil to each side of this strip is tilled (Weibel et al., 2007). Weed control around the tree trunks can be avoided by having a low-growing vegetated strip and the narrow cultivated strip at each side of the tree row can provide a competition-free zone for tree roots (Schmid and Weibel, 2000; Weibel and Häseli, 2003). This method is reported to show the lowest costs for practical weed control without any negative effect on tree performance and yield (Stefanelli et al., 2009). The sandwich system can also decrease pests and diseases and increase biodiversity (Schmid and Weibel, 2000), improve soil conditions, and enhance nutrient cycling (Stork and Jerie, 2003; Yao et al., 2005). However, several challenges to sandwich systems must be resolved such as choosing living mulch mixtures that have minimal competition, avoiding rodent problems, and adjusting vegetation growth without any negative effects on apple yield, fruit quality, and storability.

The aims of the present study were to investigate different OFMS in an organic apple orchard adapted to a cool climate and evaluate their effects on weed management, soil nutrient content, and soil physical conditions as well as apple yield, quality, and storability to replace standard tillage with new floor management systems.

\section{Materials and Methods}

Site description and experimental design. The study was conducted in an apple (Malus domestica var. Amorosa) orchard located in Kivik, southeastern Scania, Sweden (lat. $55^{\circ} 40^{\prime} 57^{\prime \prime} \mathrm{N}$, long. $14^{\circ} 13^{\prime} 18^{\prime \prime} \mathrm{E}$ ). Mean monthly temperature at the site ranges between $-2{ }^{\circ} \mathrm{C}$ (January) and $18{ }^{\circ} \mathrm{C}$ (July) and mean annual rainfall is 600 to $700 \mathrm{~mm}$. The orchard soil is a sandy loam with pH 5.9 to 6.2 and organic matter content $1.4 \%$ to $2.0 \%$. A completely randomized block design was used with five treatments (standard mechanical cultivation and four OFMS) and four 
replicates. Each replicate consisted of 10 trees, but only the central six trees were used for measurements. The orchard was drip-irrigated, which was generally restricted to prevent leaching based on tensiometer monitoring with an iMetos (iMETOS ${ }^{\circledR}$ ag; operation manual; Pessl Instruments $\mathrm{GmbH}$ Weiz, Austria; July 2005). The apple trees were grafted onto dwarf rootstock (M9) planted in Spring 1998 (with $4 \mathrm{~m}$ between rows and $1.5 \mathrm{~m}$ within rows) and trained to a super spindle form. Pruning was performed each year in early April to maintain this shape. The orchard was fertilized each year with an organic fertilizer (Bina Blue, Garta, Sweden) providing $25 \mathrm{~g}$ nitrogen $(\mathrm{N}), 4 \mathrm{~g}$ phosphorus $(\mathrm{P})$, and $60 \mathrm{~g}$ potassium $(\mathrm{K})$ per tree in May and 7, 1.1, and $16 \mathrm{~g}$ per tree, respectively, in June. Pest control was performed according to official regulations for commercial organic apple production imposed by the Swedish Board of Agriculture (Jordbruksverket, 2014).

Orchard floor management systems. Five floor management systems were selected and established in an organic apple orchard in Mar. 2008:

1. Mechanical cultivation (M): A $1.5-\mathrm{m}$ wide strip of the tree row was tilled three times per season (May, June, and September) using a rotary cultivator (Tournesol, Pellenc, France). The tractor speed for mechanical cultivation was $\approx 5 \mathrm{~km} \cdot \mathrm{h}^{-1}$ and the tillage disturbed only the upper $8 \mathrm{~cm}$ of the soil.

2. Vinegar (V): Acetic acid (12\%) was sprayed directly on the weeds at the three- to five-leaf stage in a $0.4-\mathrm{m}$ wide strip under the trees on three occasions per season (June, July, and September) using an orchard weed sprayer (Hardi, Denmark) applying $3060 \mathrm{~L} \cdot \mathrm{ha}^{-1}$ at a driving speed of $3.5 \mathrm{~km} \cdot \mathrm{h}^{-1}$. On each side of this sprayed strip, two strips of soil (40 cm wide) were shallow-tilled by the rotary cultivator (upper $8 \mathrm{~cm}$ of the soil) using the same schedule as in treatment $\mathrm{M}$.

3. Living mulch, vegetation cover crop (L): A mixture of permanent weak grasses comprising perennial ryegrass [Lolium perenne L. cv. Greenway S $(20 \%)$ and cv. Greenfair S (30\%)], meadow grass [Poa pratensis L. cv. Conni S (45\%)], and white clover [Trifolium repens L. cv. Pirouette" (5\%)] was established in the tree row $(150 \mathrm{~cm}$ wide) in May 2008 with a seed rate of $4 \mathrm{~kg} / 100 \mathrm{~m}$ and was mown at $6-\mathrm{cm}$ height three times per season using a Perfect Solo-Swing mower (Van Wamel B.V., The Netherlands). The clippings were mulched into the tree row. The vegetative cover (living mulch and weeds) in this plot was not cut during the rest of the year.

4. Sandwich system during the growing season (SSS): The same plant mixture as in treatment $\mathrm{L}$ was established in a band (40 $\mathrm{cm}$ wide) underneath the tree canopy, with the same seed rate, each year in April and mown three times per season. The clippings were mulched into the tree row. On each side of this area, two strips of soil $(40 \mathrm{~cm}$ wide) were shallow-tilled by Pellenc (in the upper $8 \mathrm{~cm}$ of the soil) using the same schedule as in treatment $M$. Each year after harvesting, the whole soil area under the tree canopy was tilled in mid-November. In June 2009 and 2010 , this plot was given an additional dose of the same fertilizer (Bina Blue) as used for base fertilization, supplying $3 \mathrm{~g} \mathrm{~N}, 0.5 \mathrm{~g} \mathrm{P}$, and $7 \mathrm{~g} \mathrm{~K}$ per tree, to reduce $\mathrm{N}$ deficiency, which was noted in the 2008 season.

5. Sandwich system during the whole year (SSW): The same plant mixture as in treatment $\mathrm{L}$ was established in a narrow strip ( $40 \mathrm{~cm}$ wide) underneath the tree canopy, with the same seed rate, in Apr. 2008 and mown three times per season. The clippings were mulched into the tree row. On both sides of the area, two strips of soil (40 cm wide) were mechanically tilled as described previously. The vegetation strip was left undisturbed during the rest of the year.

Weed evaluation. Vegetative cover was visually evaluated in each plot in each year according to Hansson and Ascard (2002) and Melander (1997). An area of $5.6 \mathrm{~m}^{2}(5 \times$ $1.125 \mathrm{~m}$ per plot) was randomly chosen and cover weeds were cut, counted, and identified to species level. However, only weed data for the last year are reported here, because the effect of each OFMS increased with time, although there were no significant differences between the 2009 and 2010 seasons. In 2010 , for example, weed assessments were performed on the following dates: 6 Apr., 25 May, 7 and 21 June, 2 and 19 July, 9 Aug., and 22 Sept. The effectiveness of each OFMS was evaluated as percentage weed cover.

Soil nutrient availability. Soil samples from 0 - to $20-\mathrm{cm}$ depth were randomly collected with a metal corer in April and July in 2009 and 2010. Visible weed residues were removed. Each sample was a composite obtained by mixing five cores, each taken at the midpoint between two trees in the replicate. The samples were stored in paper bags (four bags per OFMS) at 5 to $6{ }^{\circ} \mathrm{C}$ until analysis. Inorganic nitrogen $\left(\mathrm{NO}_{3}{ }^{-}\right)$was measured using a colorimetric method (Page et al., 1982). Other nutrient concentrations were determined by the atomic absorption spectroscopy (AAS).

Soil respiration. Soil samples were collected in late June 2009 and 2010. Five subsamples of $20 \mathrm{~g}$ were extracted in metal cores $(3 \mathrm{~cm}$ diameter) to a depth of $20 \mathrm{~cm}$ within each replicate at the midpoint between every two trees. The subsamples were mixed together and kept in a cold room $\left(5\right.$ to $\left.6{ }^{\circ} \mathrm{C}\right)$ for $30 \mathrm{~h}$. A 20 -g portion was taken from this composite sample, placed in a sealed jar, and incubated with a $0.5 \mathrm{M} \mathrm{NaOH}$ alkali $\mathrm{CO}_{2}$ trap. Soil respiration $\left(\mathrm{CO}_{2}\right.$ production) was estimated weekly for 1 month (1 week of incubation per measurement) using a gas chromatograph (Varian Inc. 3700; two-column Hayesep Q1/4" $\times 8^{\prime \prime}$ and Molsict 5, 3/8" $\times 3^{\prime \prime}$ ) as described by Alef (1998).

Soil moisture. All weather data (rainfall, air temperature, soil moisture) were measured by iMETOS®ag (Pessl Instruments $\mathrm{GmbH})$ and stored in an Internet climate database. Trees were irrigated when the water deficit exceeded $40 \mathrm{cBar}$.

Plant analysis, tree nutrition, and light intensity. Light penetration within the canopy was estimated randomly in each plot at 1500 HR local time on a sunny day, once a week during July to August in 2009 and 2010. These measurements were conducted at the center of the trunk, from four directions along the crown and $70 \mathrm{~cm}$ above the ground, using a light meter (L1-188; L1-COR, Frederickson, Copenhagen, Denmark). Full sunlight was measured (at the same time and height) in a free area (between rows). Sunlight penetration was calculated as the amount of sunlight that reached the orchard floor and midcanopy compared with full sunlight. This was done by dividing the photosynthetic photon flux $(P P F)$ within the canopy at the four positions by the simultaneously recorded open sky $P P F$ subtracting the value obtained from 1 and expressing the result as a percentage. A sample of leaves was taken randomly from the same trees in each plot in June and September every year under similar weather conditions. Each leaf sample contained 100 new midterminal leaves from current-year shoots in the center section of the tree. The leaves were washed with distilled water, dried at $60{ }^{\circ} \mathrm{C}$, and analyzed by AAS for determination of $\mathrm{P}, \mathrm{K}$, calcium, and magnesium and by the Kjeldahl method for determination of total N. Leaf greenness was also estimated weekly in June and September using a handheld chlorophyll meter (SPAD, Hydro, Sweden) on 30 midterminal leaves per plot and week. A sample of 30 apples was picked randomly from each plot 3 weeks before normal commercial harvesting time and analyzed for macroand micronutrients as described previously.

Tree performance and yield. Tree growth was estimated by two measurements: 1) trunk growth: the differential increase in trunk cross-section area (TCSA, $\mathrm{cm}^{2}$ ) was measured every year in April at $30 \mathrm{~cm}$ above graft union $\left(\right.$ TCSA $\left.=\operatorname{radial}^{2} \times \pi\right)$; and 2) shoot growth: three shoots were randomly selected at the bottom, center, and top sections of each experimental tree. Shoot length was measured using a ruler in April and October during each season to evaluate shoot extension [new growth $\%=($ length in October length in April $\left.) \times(\text { length in April })^{-1}\right]$.

Apple yield ( $\left.\mathrm{t} \cdot \mathrm{ha}^{-1}\right)$, number of fruit, and cumulative yield during the 3 years were recorded. Yield efficiency was calculated as total yield divided by TCSA in the previous year.

Fruit quality and storage potential. Fruit maturity was evaluated by estimating 
ethylene production on three fruits per tree and plot twice a week during August to September each year. The fruits were placed in 0.5 - $\mathrm{L}$ jars at $20^{\circ} \mathrm{C}$, which were sealed for 3 to $4 \mathrm{~h}$ before measurements. Ethylene was quantified by gas chromatography (Agilent GC 6850) equipped with a flame ionization detector, automatic gas sampling valve $1000 \mu \mathrm{L}, 150{ }^{\circ} \mathrm{C}$, and fitted with a capillary column HP plot Q $30 \times 0.53 \mathrm{~mm} \times 40 \mu \mathrm{m}$ (Agilent). Analyses were run isothermally with an oven temperature of $70{ }^{\circ} \mathrm{C}$ and a detector temperature of $250{ }^{\circ} \mathrm{C}$. The flow rate used for $\mathrm{N}$, hydrogen, and compressed air was 20,45 , and $225 \mathrm{~mL} \cdot \mathrm{min}^{-1}$ respectively. Ethylene was quantified by peak area and external standards were used for calibration. Evaluations and calculations were carried out with Chemstation version 9.03 (Agilent Corp). At the optimal date for var. Amorosa, when ethylene production reached at least 0.1 to $0.5 \mu \mathrm{L} \cdot \mathrm{L}^{-1} \cdot \mathrm{kg}^{-1} \cdot \mathrm{h}^{-1}$ according to Tahir (2006), fruits were harvested, weighed, counted, and their quality evaluated. In all treatments, the following fruit quality parameters were estimated in four replicate samples of 40 fruits per treatment:

- Fruit coloration was measured by a colorimeter (Chromameter, Model CR200 with an 8-mm diameter window; Minolta Camera Co., Ltd., Osaka, Japan) and expressed as $+a^{*}$ for red color, $-a^{*}$ for green color, $+\mathrm{b}^{*}$ for yellow color, $-\mathrm{b}^{*}$ for blue color, and L for luminosity. Skin color variations were expressed as color index $\left[\mathrm{CI}=\left(1000 \times \mathrm{a}^{*}\right)\left(\mathrm{L} \times \mathrm{b}^{*}\right)^{-1}\right]($ Camelo and Gomez, 2004).

- Firmness was measured on opposite, peeled sides of each fruit using a penetrometer (Model FT 327; Effegi, Italy; plunger diameter $11.1 \mathrm{~mm}$, depth $7.9 \mathrm{~mm}$ ) and the results expressed as Newton.

- Titratable acidity (TA) was measured as malic acid on juice extracted from composite samples of segments of 10 fruits per tree using a titration unit (Titroline Easy; SCHOTT Instr. GmbH, Germany) and $0.1 \mathrm{M} \mathrm{NaOH}$ to an endpoint of $\mathrm{pH} 8.2$ and the results expressed as \% acid (v/v).

- The extracted juice was also used for measurement of soluble solids concentration (SSC) using a refractometer (Atago PR-100; Atago Co. Ltd., Tokyo, Japan) and the results expressed as ${ }^{\circ}$ Brix, which are equivalent to $\%$ sugar $(\mathrm{w} / \mathrm{w})$ at $20{ }^{\circ} \mathrm{C}$. - Taste was evaluated as SSC:TA ratio.

A sample of 25 fruits was picked from the inside and outside the top and center sections of each tree (a composite sample of 150 fruits per replicate) and stored in controlled-atmosphere storage (CA; $2.0 \mathrm{kPa} \mathrm{O}_{2}$ and $2.0 \mathrm{kPa} \mathrm{CO}_{2}$ ) for 4 months. CA storage was achieved in computer-controlled 350-L chambers (Ninolab, Upplands Väsby, Sweden) with gas composition established $3 \mathrm{~d}$ before placing the apples in the chambers. Post-storage quality was estimated for 15 fruits per OFMS and replicate. Because fruit can develop an undesirable "mealy" texture when kept at room temperature for daily home consumption or by small-scale distributors and retailers (Varela et al., 2005), fruit quality must be properly assessed after storage at ambient conditions. Therefore, stored fruits were kept after storage in a plastic chamber at $18 \pm 2{ }^{\circ} \mathrm{C}$ and $80 \%$ relative humidity for 1 week (shelf life) before evaluation of quality and storability. Fruit storage potential was estimated according to the changes in different quality parameters and the occurrence of fungal and physiological disorders during storage and shelf life. The incidence of physiological disorders (soft scald, flesh browning, and internal breakdown) and storage rots was determined according to Sandskär (2005) and Tahir (2006) and expressed as percentage of damaged fruit.

Statistical analysis. Data were analyzed with a mixed-model analysis of variance with year (2008-10), OFMS and their interactions as fixed effects for weed cover, tree growth (TCSA and shoot extension), soil nutrient, leaf greenness, leaf and fruit nutrient content, light transmission, yield, fruit quality parameters at harvest, post-storage, and after shelf life and storage decay. Multiple comparisons were made with Tukey's post hoc test ( $\alpha=$ 0.05 ). In all analyses, the Minitab 16 program was used.

\section{Results}

Weed control. The various OFMS had significantly different effects $(P<0.05)$ on weeds. During the season (April to September), the treatment with $\mathrm{L}$ had the highest weed cover, $\approx 48 \%$ including the $\mathrm{L}$, compared with $18.3 \%$ for mechanical cultivation (M) and $20.0 \%$ for V. Both sandwich systems showed lower weed density, with $\approx 25 \%$ for SSW (during the whole year) and 31\% for SSS (during the season). Weed growth was relatively weak before and during the flowering period and rapidly increased in all plots during the 2 weeks thereafter $(P<0.05$, e.g., in 2010 season) (Fig. 1). Between 13 and $65 \mathrm{~d}$ after full bloom (DAFB), weed biomass decreased in all plots except L, where they increased or at least remained high (Fig. 1). The $\mathrm{M}$ and $\mathrm{V}$ treatments had greater suppressive effects on weeds than either of the sandwich systems, whereas SSW restricted weed growth more strongly than SSS. However, weeds started to show very weak growth by 65 DAFB (15 July) in all OFMS. Rapid growth occurred again after 86 DAFB, resulting in non-significant differences among the five treatments (Fig. 1). The composition of weed species was relatively similar in the orchard in Spring 2008. However, it had changed significantly by Sept. 2010 as a result of the effects of different OFMS. Elymus repens L. and Chenopodium album $\mathrm{L}$. were the most common weeds with the former found in 16 of 20 plots and the latter in five of 20 plots. These two types of weeds are the most frequently occurring in Swedish orchards. A noteworthy finding was that the different OFMS affected the two weed species differently. Elymus repens was less frequent in treatment $\mathrm{L}$ and Chenopodium album was less frequent in treatments V and SSS than in the other OFMS in the study. However, the number of weed species was higher in both sandwich systems compared with the other OFMS, whereas the weed species were less aggressive than the L, partly depending on the regular mowing.

Yield, fruit weight, and yield efficiency. The effects of the OFMS on apple yield and yield efficiency were more consistent throughout the 3-year study period. Treatment SSW had no negative effect on cumulative yield, whereas $\mathrm{V}$ increased it by $10 \%$ and $\mathrm{L}$ and SSS decreased yield by $20 \%$ and $10 \%$, respectively, compared with the $\mathrm{M}$ treatment $(P<0.05)$ (Table 1$)$. In 2008 there were no clear differences between systems, whereas during the third year (2010), the negative effect of the L and SSS treatments on yield was more obvious (Table 1). In 2008, the $\mathrm{L}$ and sandwich systems decreased fruit weight by $10 \%$ compared with M and V. During 2009 and 2010, only SSS had this negative effect, whereas SSW increased fruit weight by $13 \%$ compared with $\mathrm{M}$ and $\mathrm{V}$. However, most of the small fruit

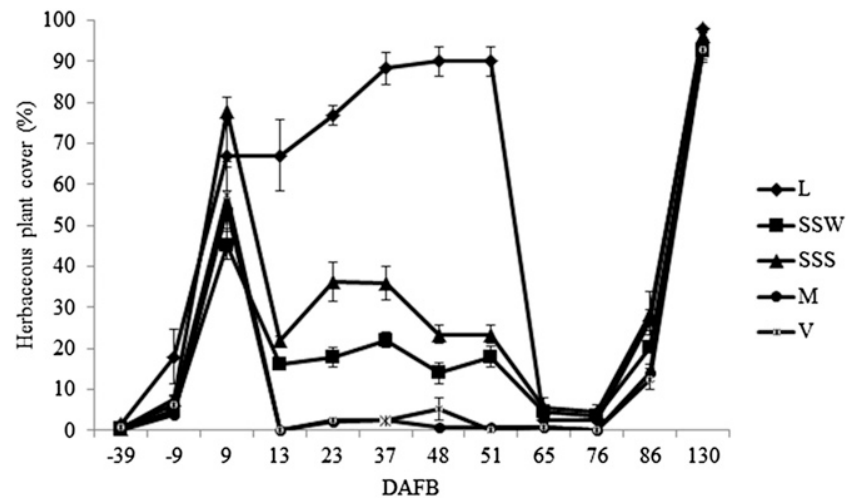

Fig. 1. Weed cover (incl. living mulch) during the season 2010 in relation to application of different orchard floor management systems (OFMS) (controlled area $5.6 \mathrm{~m}^{2}$ ). L = Living mulch; SSW = sandwich system during whole year; SSS = sandwich system during the season; $\mathrm{M}=$ mechanical cultivation; $\mathrm{V}=$ vinegar treatment; $\mathrm{DAFB}=$ days after full blooming. Bars represent confidence interval between OFMS at $P \leq 0.05$ according to Tukey's test. 
were found in SSS plots, whereas the other systems resulted in economically optimum fruit weight of 125 to $140 \mathrm{~g}(P<0.05)$ (Table 1).

Trees in L and SSS plots also showed lower yield efficiency during the 3 years. However, the yield efficiency of trees in SSS plots improved later, resulting in a significant difference compared with L. Treatments SSW and M had the highest yield efficiency followed by V (Table 1). There was a linear correlation between yield and weed cover. During the season, a reduction of weed cover by $10 \%$ increased apple yield by $4 \mathrm{t} \cdot \mathrm{ha}^{-1}\left(R^{2}=\right.$ 0.537; $P=0.001$ ) (Fig. 2A). The most important period was found to be between late May and mid-July, because reducing weed density (by $10 \%$ ) only during these 6 weeks increased fruit yield by $1.8 \mathrm{t} \cdot \mathrm{ha}^{-1}\left(R^{2}=\right.$ $0.539 ; P=0.001$ ) (Fig. 2B). There was no clear relationship between weed cover during the preharvest period and apple yield.

Tree growth. The OFMS influenced tree growth with significant differences between treatments $(P<0.05)$. TCSA showed a higher increase for trees in SSW plots followed by trees in V and M plots, whereas SSS and L plots showed the lowest development (Table 2). In 2009, trees in M and V plots had the highest shoot extension followed equally by trees in other plots $(P<0.05)$ (Table 2$)$. The lowest extension was found in SSS plots. Again in 2010, M caused the highest shoot growth followed by V, SSW, L, and SSS in that order. However, the L and SSS treatments significantly $(P<0.05)$ reduced the growth rate of the canopy during the study (Table 2).

Soil fertility. In April and July in 2009 and 2010, soil N concentration in the L and SSS plots was lower than that in the M and V plots. The SSW plots had a higher $\mathrm{N}$ content than the L and SSS plots in Apr. 2009, but these differences disappeared in July, resulting in lower $\mathrm{N}$ content compared with $\mathrm{M}$ and V plots $(P<0.05)$ (Table 3). Again in 2010, the SSW plot contained higher soil nitrogen than the L and SSS plots. Soil K concentration was significantly greater in L, SSS, and SSW plots during 2010 than in M and V plots. Corresponding differences were not observed in 2009. Different OFMS did not affect magnesium and $\mathrm{P}$ content in the soil (data not shown). SSW plots had higher soil calcium content during 2009 and 2010, whereas SSS and $\mathrm{L}$ had lower soil calcium in 2009 than the $\mathrm{M}$ and $\mathrm{V}$ plots. Soil $\mathrm{pH}$ in the plots with acetic acid added (V) was not higher than in the other OFMS plots (Table 3).

Soil respiration. Cumulative $\mathrm{CO}_{2}$ levels in soil samples from $\mathrm{L}$ and sandwich plots were higher than in the soil samples from $\mathrm{M}$ and V. However, only soil from SSW and SSS continued to show relatively high respiration at the end of the study period in July (both years), whereas no significant differences were found among the other three treatments $(P<0.05)$ (Fig. 3).

Light intensity. Measurements of light penetration into the tree canopy did not show any clear differences between OFMS in July 2009, but both sandwich systems and the L

Table 1. Various orchard floor management systems (OFMS) affect yield and fruit weight in an organic apple orchard during 2008-10.

\begin{tabular}{|c|c|c|c|c|c|c|c|}
\hline \multirow[b]{2}{*}{$\mathrm{OFMS}^{\mathrm{z}}$} & \multicolumn{3}{|c|}{ Yield $\left(\mathrm{t} \cdot \mathrm{ha}^{-1}\right)$} & \multirow[b]{2}{*}{ Cumulative yield } & \multicolumn{3}{|c|}{ Fruit wt (g) } \\
\hline & 2008 & 2009 & 2010 & & 2008 & 2009 & 2010 \\
\hline$\overline{\mathrm{M}}$ & $13.8 \mathrm{a}^{\mathrm{y}}$ & $11.4 \mathrm{c}$ & $19.5 \mathrm{a}$ & $44.7 \mathrm{~b}$ & $139.5 \mathrm{a}^{\mathrm{y}}$ & $101.8 \mathrm{~b}$ & $123.5 \mathrm{c}$ \\
\hline V & $12.9 \mathrm{ab}$ & $16.4 \mathrm{a}$ & $19.5 \mathrm{a}$ & $48.8 \mathrm{a}$ & $147.6 \mathrm{a}$ & $104.4 \mathrm{~b}$ & $130.7 \mathrm{~b}$ \\
\hline $\mathrm{L}$ & $11.9 \mathrm{~b}$ & $10.9 \mathrm{c}$ & $12.8 \mathrm{~b}$ & $35.6 \mathrm{~d}$ & $123.3 \mathrm{~b}$ & $131.3 \mathrm{a}$ & $128.2 \mathrm{~b}$ \\
\hline SSS & $11.1 \mathrm{~b}$ & $13.8 \mathrm{~b}$ & $15.6 \mathrm{~b}$ & $40.5 \mathrm{c}$ & $125.5 \mathrm{~b}$ & $97.3 \mathrm{~b}$ & $118.7 \mathrm{~d}$ \\
\hline SSW & $11.4 \mathrm{~b}$ & $13.4 \mathrm{~b}$ & $19.0 \mathrm{a}$ & $43.8 \mathrm{~b}$ & $127.5 \mathrm{~b}$ & $134.8 \mathrm{a}$ & $154.8 \mathrm{a}$ \\
\hline
\end{tabular}

${ }^{\mathrm{z}} \mathrm{OFMS}=$ orchard floor management systems; $\mathrm{M}=$ mechanical cultivation; $\mathrm{V}=$ vinegar treatment; $\mathrm{L}=$ living mulch; $\mathrm{SSS}=$ sandwich system during the season; $\mathrm{SSW}=$ sandwich system during whole year. ${ }^{y}$ Values followed by the same letter are not significantly different at $P \leq 0.05$ according to Tukey's test.
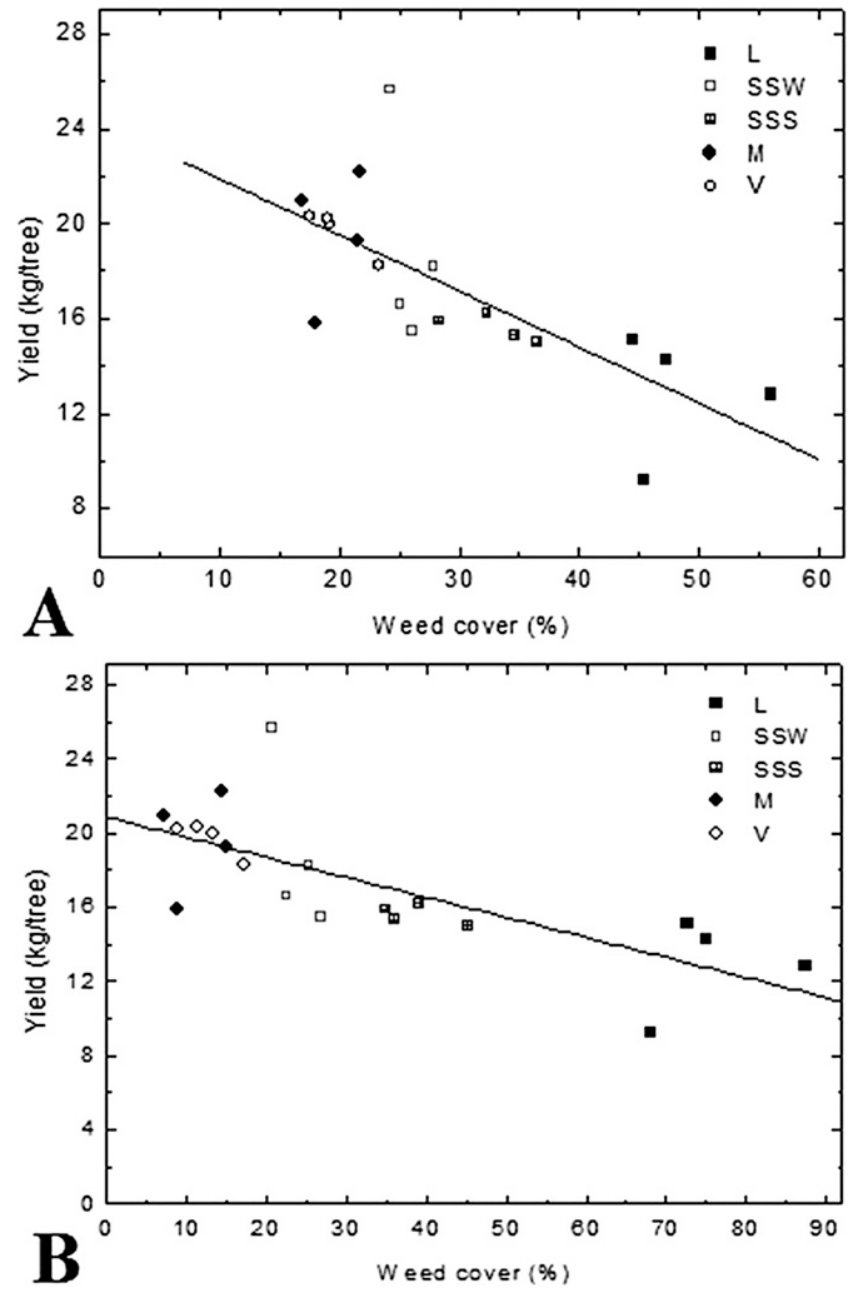

Fig. 2. Correlation between average weed cover and yield (season 2010) (A) during the season (6 Apr. to 22 Sept.), regression line $\mathrm{f}(\mathrm{x})=24,254-0,2363 * \mathrm{x} . R^{2}$ value $=0.539 . R=0.734\left(\mathrm{R} * \mathrm{R}=R^{2}\right), P=0.001$ for regression. (B) During the cell division period (15 May to 2 July), regression line $\mathrm{f}(\mathrm{x})=20.836-$ $0.1079 * x . R^{2}$ value $=0.537 . R=0.733 . P=0.001$ for regression. OFMS $=\mathrm{L}=$ living mulch; $\mathrm{SSW}=$ sandwich system during whole year; SSS = sandwich system during the season; $\mathrm{M}=$ mechanical cultivation; $\mathrm{V}=$ vinegar treatment.

treatment improved light intensity in Aug. 2009 and in the whole 2010 season compared with $\mathrm{M}$ and $\mathrm{V}$ plots $(P<0.05)$ (Table 4$)$. Fruit from $L$ and sandwich system plots had higher coloration than fruit from $\mathrm{M}$ and $\mathrm{V}$ plots (Table 4). The results were clearer in the 2010 season. A positive significant correlation was found between light intensity during August and fruit coloration at harvest in all plots (Pearson; $r=0.89$ and 0.92 in 2009 and 2010, respectively). No significant correlation was found between light intensity in July and fruit coloration.
Leaf nutrient content. Tree leaves in the $\mathrm{M}$ and $\mathrm{V}$ plots had a higher $\mathrm{N}$ content that those in the other OFMS plots during Sept. 2009 and in June and Sept. $2010(P<0.05)$ (Table 5). These two systems also showed better leaf greenness compared with SSS and L (Table 5). A strong correlation between leaf greenness and $\mathrm{N}$ content (Pearson $r=$ 0.9144 ) was found only in June 2009 and 2010. Although SPAD readings (chlorophyll) increased in September of other years, N content as a percentage of dry matter did not change, regardless of OFMS. Leaves 
Table 2. Various orchard floor management systems (OFMS) affect tree growth and yield efficiency in an organic apple orchard during 2008-2010.

\begin{tabular}{|c|c|c|c|c|c|c|c|c|}
\hline \multirow[b]{2}{*}{ OFMS $^{z}$} & \multirow{2}{*}{$\begin{array}{c}\operatorname{TCSA}^{\mathrm{y}}\left(\mathrm{cm}^{2}\right) \\
\text { Apr. } 2008\end{array}$} & \multicolumn{2}{|c|}{ Development of TCSA during the study $(\%)^{x}$} & \multicolumn{3}{|c|}{ Yield efficiency (yield/TCSA) $\left(\mathrm{g} \cdot \mathrm{cm}^{-2}\right)$} & \multicolumn{2}{|c|}{ Shoot extension (cm per season) } \\
\hline & & Apr. 2009 & Apr. 2010 & 2008 & 2009 & 2010 & 2009 & 2010 \\
\hline $\mathrm{V}$ & 33.2 & $14.2 \mathrm{c}$ & $20.1 \mathrm{~b}$ & $0.24 \mathrm{~b}$ & $0.22 \mathrm{~b}$ & $0.22 \mathrm{~b}$ & $23.0 \mathrm{a}$ & $24.9 \mathrm{~b}$ \\
\hline $\mathrm{L}$ & 38.5 & $15.0 \mathrm{~b}$ & $13.0 \mathrm{~d}$ & $0.19 \mathrm{c}$ & $0.17 \mathrm{c}$ & $0.18 \mathrm{c}$ & $20.0 \mathrm{~b}$ & $20.5 \mathrm{c}$ \\
\hline SSW & 26.4 & $16.0 \mathrm{a}$ & $24.5 \mathrm{a}$ & $0.26 \mathrm{ab}$ & $0.26 \mathrm{a}$ & $0.30 \mathrm{a}$ & $20.7 \mathrm{~b}$ & $23.6 \mathrm{~b}$ \\
\hline
\end{tabular}

${ }^{\mathrm{z}} \mathrm{OFMS}=$ orchard floor management systems; $\mathrm{M}=$ mechanical cultivation; $\mathrm{V}=$ vinegar treatment; $\mathrm{L}=$ living mulch; $\mathrm{SSS}=$ sandwich system during the season; $\mathrm{SSW}=$ sandwich system during whole year.

${ }^{\mathrm{y}} \mathrm{TCSA}=$ trunk cross-sectional area.

${ }^{x}$ Development in $\%=(\text { TCSA in April of this season - TCSA in April of the last season)/(TCSA in April of the last season })^{-1}$.

wValues followed by the same letter are not significantly different at $P \leq 0.05$ according to Tukey's test.

from the L, SSS, and SSW plots had lower K content in June of both years (2009 and 2010) compared with $\mathrm{M}$ and $\mathrm{V}$ plots. These significant differences disappeared in September. In both seasons, leaf calcium content remained higher in trees from L, SSS, and SSW plots compared with trees from the M and $\mathrm{V}$ plots (Table 5). The magnesium and $\mathrm{P}$ contents in leaves were unaffected in both June and September (data not shown).

Fruit quality. A clear effect of various OFMS on fruit maturation was observed. Changes in ethylene production were earlier and faster in fruit from $\mathrm{M}$ and $\mathrm{V}$ plots compared with fruit from $\mathrm{L}$ and both sandwich systems (Fig. 4; e.g., $P<0.05$ for 2010 ). The different OFMS did not give any significant effects on fruit quality at harvest regarding, e.g., flesh firmness, SSC, acidity (TA), and fruit taste (SSC:TA ratio) (data not shown). A clear relationship was observed between OFMS and fruit coloration and potassium:calcium $(\mathrm{K}: \mathrm{Ca})$ ratio, because the $\mathrm{L}$ and sandwich systems improved fruit coloration (Table 4) and had a lower $\mathrm{K}: \mathrm{Ca}$ ratio 3 weeks before harvesting compared with $\mathrm{M}$ and $\mathrm{V}(P<0.05)$ (Table 6$)$.

Fruit storage potential. Because no storage disorders were noted during the three seasons, analysis of storage decay was restricted to fungal diseases. Amount of fungal decay increased as a result of $M$ in comparison with the $\mathrm{V}$ and SSW treatments in the 2008 season and in comparison with all other OFMS treatments in the 2010 season (Table 6). No significant differences between OFMS were found in 2009. The main agents of this decay were Neofabraea sp., Penicillium expansum, and Fusarium sp. Fruit softening during storage was unaffected by different OFMS except in SSW plots, where fruit showed less softening in 2008 and 2009 compared with fruit from other OFMS plots. During shelf life studies, fruits from the L and sandwich systems plots were $25 \%$ firmer than fruits from the $\mathrm{M}$ plots and showed lower softening $(P<0.05)$ (Table 7$)$. SSC in all fruits increased during storage and decreased during shelf life. No significant differences between OFMS were found (data not shown). Fruit acidity declined during storage and shelf life. Acidity was better maintained in fruits from SSW plots after storage and in fruits from L, SSS, and SSW after shelf life compared with fruits from M plots (Table 7). Fruit taste changed during storage as a result

Table 3. Soil nutrient availability resulting from different orchard floor management systems (OFMS) in an organic apple orchard, which was fertilized in May and June.

\begin{tabular}{|c|c|c|c|c|c|c|c|c|c|c|}
\hline \multirow[b]{4}{*}{ OFMS $^{z}$} & \multicolumn{4}{|c|}{ Season 2009} & \multirow[b]{4}{*}{$\mathrm{pH}$} & \multicolumn{4}{|c|}{ Season 2010} & \multirow[b]{4}{*}{$\mathrm{pH}$} \\
\hline & \multirow{2}{*}{\multicolumn{2}{|c|}{$\mathrm{NO}_{3}\left(\mathrm{~kg} \cdot \mathrm{ha}^{-1}\right)$}} & \multirow{2}{*}{\multicolumn{2}{|c|}{$\frac{\mathrm{Mg} / 100 \mathrm{~g}}{\mathrm{DW}, \mathrm{July}}$}} & & \multirow{2}{*}{\multicolumn{2}{|c|}{$\mathrm{NO}_{3}\left(\mathrm{~kg} \cdot \mathrm{ha}^{-1}\right)$}} & \multirow{2}{*}{\multicolumn{2}{|c|}{$\begin{array}{l}\mathrm{Mg} / 100 \mathrm{~g} \\
\mathrm{DW}, \text { July }\end{array}$}} & \\
\hline & & & & & & & & & & \\
\hline & April & $\overline{\text { July }}$ & $\overline{\mathrm{K}}$ & $\mathrm{Ca}$ & & April & July & $\mathrm{K}$ & $\mathrm{Ca}$ & \\
\hline $\bar{M}$ & $16.9 \mathrm{a}^{\mathrm{y}}$ & $48.4 \mathrm{a}$ & $30 \mathrm{a}$ & $120 \mathrm{~b}$ & $6.2 \mathrm{a}$ & $15.4 \mathrm{a}$ & $36.0 \mathrm{a}$ & $30 \mathrm{c}$ & $120 \mathrm{~b}$ & $6.3 \mathrm{a}$ \\
\hline $\mathrm{V}$ & $17.5 \mathrm{a}$ & $49.5 \mathrm{a}$ & $23 \mathrm{~b}$ & $120 \mathrm{~b}$ & $6.3 \mathrm{a}$ & $16.5 \mathrm{a}$ & $34.4 \mathrm{a}$ & $31 \mathrm{c}$ & $120 \mathrm{~b}$ & $6.7 \mathrm{a}$ \\
\hline $\mathrm{L}$ & $10.6 \mathrm{c}$ & $35.9 \mathrm{~b}$ & $31 \mathrm{a}$ & $108 \mathrm{c}$ & $6.1 \mathrm{a}$ & $9.6 \mathrm{~b}$ & $20.6 \mathrm{c}$ & $35 \mathrm{~b}$ & $110 \mathrm{~b}$ & $6.1 \mathrm{a}$ \\
\hline SSS & $12.0 \mathrm{c}$ & $36.7 \mathrm{~b}$ & $31 \mathrm{a}$ & $87 \mathrm{~d}$ & $5.8 \mathrm{a}$ & $11.5 \mathrm{~b}$ & $22.1 \mathrm{c}$ & $42 \mathrm{a}$ & $120 \mathrm{~b}$ & $6.3 \mathrm{a}$ \\
\hline SSW & $13.9 \mathrm{~b}$ & $39.8 \mathrm{~b}$ & $32 \mathrm{a}$ & $130 \mathrm{a}$ & $6.2 \mathrm{a}$ & $14.1 \mathrm{a}$ & $27.6 \mathrm{~b}$ & $36 \mathrm{~b}$ & $140 \mathrm{a}$ & $6.3 \mathrm{a}$ \\
\hline
\end{tabular}

${ }^{\mathrm{z}} \mathrm{OFMS}=$ orchard floor management systems; $\mathrm{M}=$ mechanical cultivation; $\mathrm{V}=$ vinegar treatment; $\mathrm{L}=$ living mulch; SSS = sandwich system during the season; SSW = sandwich system during whole year.

${ }^{y}$ Values followed by the same letter are not statistically different at $P \leq 0.05$ according to Tukey's test. Because no significant differences between OFMS were found, data for phosphorus and magnesium not shown.

$\mathrm{Mg}=$ magnesium; $\mathrm{DW}=$ dry weight $\mathrm{K}=$ potassium $; \mathrm{Ca}=$ calcium .
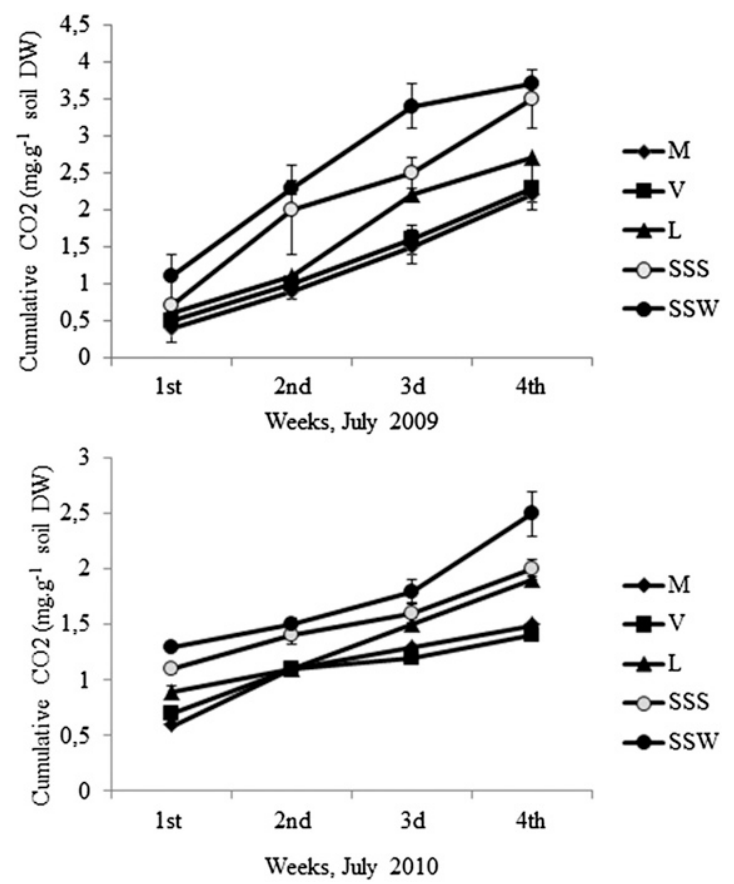

Fig. 3. Effects of different orchard floor management systems (OFMS) on soil respiration rates measured weekly during July 2009 and $2010(\mathrm{n}=20)$. $\mathrm{L}=$ living mulch; SSW = sandwich system during whole year; $\mathrm{SSS}=$ sandwich system during the season; $\mathrm{M}=$ mechanical cultivation; $\mathrm{V}=$ vinegar treatment. Bars represent confidence interval between OFMS at $P \leq 0.05$ according to Tukey's test.

of acidity decline. A lower negative change was detected in fruits from SSW plots after storage and in fruits from L, SSS, and SSW after shelf life as a result of a moderate increase in SSC and less TA deterioration (Table 7).

\section{Discussion}

In organic apple orchards, one of the most serious challenges is to achieve active integration between limiting weed competition, availability of nutrients, optimal tree growth, 
Table 4. Light intensity and fruit coloration resulting from application of different orchard floor management systems (OFMS) in an organic apple orchard.

\begin{tabular}{|c|c|c|c|c|c|c|}
\hline \multirow[b]{3}{*}{$\mathrm{OFMS}^{\mathrm{z}}$} & \multicolumn{4}{|c|}{ Light intensity (\%) } & & \\
\hline & \multicolumn{2}{|c|}{2009} & \multicolumn{2}{|c|}{2010} & \multicolumn{2}{|c|}{ Fruit color index ${ }^{y}$} \\
\hline & July & August & July & August & 2009 & 2010 \\
\hline$\overline{\mathrm{M}}$ & $51.8 \mathrm{~b}^{\mathrm{x}}$ & $45.0 \mathrm{c}$ & $52.0 \mathrm{~b}$ & $45.8 \mathrm{c}$ & $11.1 \mathrm{c}$ & $7.2 \mathrm{~d}$ \\
\hline V & $46.0 \mathrm{c}$ & $44.5 \mathrm{c}$ & $42.6 \mathrm{c}$ & $48.4 \mathrm{c}$ & $10.3 \mathrm{c}$ & $13.5 \mathrm{c}$ \\
\hline $\mathrm{L}$ & $48.5 \mathrm{bc}$ & $55.5 \mathrm{~b}$ & $55.9 \mathrm{a}$ & $53.8 \mathrm{~b}$ & $19.2 \mathrm{a}$ & $17.4 \mathrm{a}$ \\
\hline SSS & $55.7 \mathrm{a}$ & $53.6 \mathrm{~b}$ & $54.8 \mathrm{a}$ & $54.0 \mathrm{~b}$ & $16.2 \mathrm{~b}$ & $15.4 \mathrm{~b}$ \\
\hline SSW & $55.5 \mathrm{a}$ & $58.2 \mathrm{a}$ & $57.0 \mathrm{a}$ & $59.7 \mathrm{a}$ & $11.6 \mathrm{c}$ & $19.3 \mathrm{a}$ \\
\hline
\end{tabular}

${ }^{\mathrm{z}} \mathrm{OFMS}=$ orchard floor management systems; $\mathrm{M}=$ mechanical cultivation; $\mathrm{V}=$ vinegar treatment; $\mathrm{L}=$ living mulch; SSS = sandwich system during the season; SSW = sandwich system during whole year. ${ }^{\mathrm{y}}$ Color index $=\left(1000 \times \mathrm{a}^{*}\right) /\left(\mathrm{L}^{*} \times \mathrm{b}^{*}\right)^{-1}$. Light intensity was measured by dividing the photosynthetically photon flux $(P P F)$ within the canopy at the four positions by the simultaneously recorded open sky $P P F$, subtracting the value obtained from 1 and expressing the result as a percentage.

'Values followed by the same letter are not statistically different at $P \leq 0.05$ according to Tukey's test.

Table 5. Tree leaf mineral content during the season as a result of application of different orchard floor management systems (OFMS) in an organic apple orchard. ${ }^{2}$

\begin{tabular}{|c|c|c|c|c|c|c|c|c|c|}
\hline \multirow[b]{2}{*}{ Season } & \multirow[b]{2}{*}{$\mathrm{OFMS}^{\mathrm{y}}$} & \multicolumn{2}{|c|}{ Chlorophyll } & \multicolumn{2}{|c|}{ Nitrogen } & \multicolumn{2}{|r|}{$\mathrm{K}$} & \multicolumn{2}{|r|}{$\mathrm{Ca}$} \\
\hline & & June & September & June & September & June & September & June & September \\
\hline \multirow[t]{5}{*}{2009} & $\mathrm{M}$ & $37.2 \mathrm{ab}^{\mathrm{x}}$ & $55.5 \mathrm{a}$ & $2.4 \mathrm{ab}$ & $3.0 \mathrm{a}$ & $2.0 \mathrm{a}$ & $2.1 \mathrm{a}$ & $0.9 \mathrm{a}$ & $0.8 \mathrm{~d}$ \\
\hline & V & $38.9 \mathrm{a}$ & $58.1 \mathrm{a}$ & $2.7 \mathrm{a}$ & $3.1 \mathrm{a}$ & $1.9 \mathrm{a}$ & $2.0 \mathrm{a}$ & $0.9 \mathrm{a}$ & $0.9 \mathrm{~cd}$ \\
\hline & $\mathrm{L}$ & $35.5 \mathrm{ab}$ & $40.3 \mathrm{~d}$ & $1.9 \mathrm{~cd}$ & $2.3 \mathrm{~b}$ & $1.4 \mathrm{~b}$ & $2.0 \mathrm{a}$ & $0.9 \mathrm{a}$ & $1.0 \mathrm{bc}$ \\
\hline & SSS & $34.0 \mathrm{~b}$ & $44.9 \mathrm{c}$ & $1.7 \mathrm{~d}$ & $2.3 \mathrm{~b}$ & $1.6 \mathrm{~b}$ & $1.9 \mathrm{a}$ & $1.0 \mathrm{a}$ & $1.1 \mathrm{~b}$ \\
\hline & SSW & $38.3 \mathrm{a}$ & $50.1 \mathrm{~b}$ & $2.2 \mathrm{bc}$ & $2.4 \mathrm{~b}$ & $1.5 \mathrm{~b}$ & $1.9 \mathrm{a}$ & $1.0 \mathrm{a}$ & $1.3 \mathrm{a}$ \\
\hline \multirow[t]{5}{*}{2010} & M & $46.0 \mathrm{a}$ & $58.8 \mathrm{a}$ & $2.6 \mathrm{a}$ & $3.0 \mathrm{a}$ & $2.3 \mathrm{a}$ & $1.9 \mathrm{~b}$ & $0.8 \mathrm{~b}$ & $1.2 \mathrm{~d}$ \\
\hline & $\mathrm{V}$ & $44.4 \mathrm{ab}$ & $58.4 \mathrm{a}$ & $2.0 \mathrm{~b}$ & $3.4 \mathrm{a}$ & $2.5 \mathrm{a}$ & $2.2 \mathrm{a}$ & $0.7 \mathrm{~b}$ & $1.3 \mathrm{~cd}$ \\
\hline & $\mathrm{L}$ & $44.8 \mathrm{a}$ & $48.4 \mathrm{c}$ & $1.7 \mathrm{~b}$ & $2.1 \mathrm{bc}$ & $2.0 \mathrm{~b}$ & $1.8 \mathrm{~b}$ & $1.5 \mathrm{a}$ & $1.8 \mathrm{a}$ \\
\hline & SSS & $45.6 \mathrm{a}$ & $45.6 \mathrm{c}$ & $1.6 \mathrm{~b}$ & $2.3 \mathrm{~b}$ & $1.6 \mathrm{c}$ & $1.8 \mathrm{~b}$ & $1.2 \mathrm{a}$ & $1.5 \mathrm{bc}$ \\
\hline & SSW & $40.8 \mathrm{~b}$ & $51.5 \mathrm{~b}$ & $1.7 \mathrm{~b}$ & $1.7 \mathrm{c}$ & $2.0 \mathrm{~b}$ & $2.1 \mathrm{a}$ & $1.2 \mathrm{a}$ & $1.5 \mathrm{bc}$ \\
\hline
\end{tabular}

${ }^{\mathrm{z}}$ Chlorophyll (SPAD) and minerals as \% of dry weight.

${ }^{\mathrm{y}} \mathrm{OFMS}=$ orchard floor management systems; $\mathrm{M}=$ mechanical cultivation; $\mathrm{V}=$ vinegar treatment; $\mathrm{L}=$ living mulch; SSS = sandwich system during the season; SSW = sandwich system during whole year.

${ }^{x}$ Values followed by the same letter are not statistically different at $P \leq 0.05$ according to Tukey's test. Because no significant differences between OFMSs were found, data for phosphorus and magnesium not shown

$\mathrm{K}=$ potassium; $\mathrm{Ca}=$ calcium

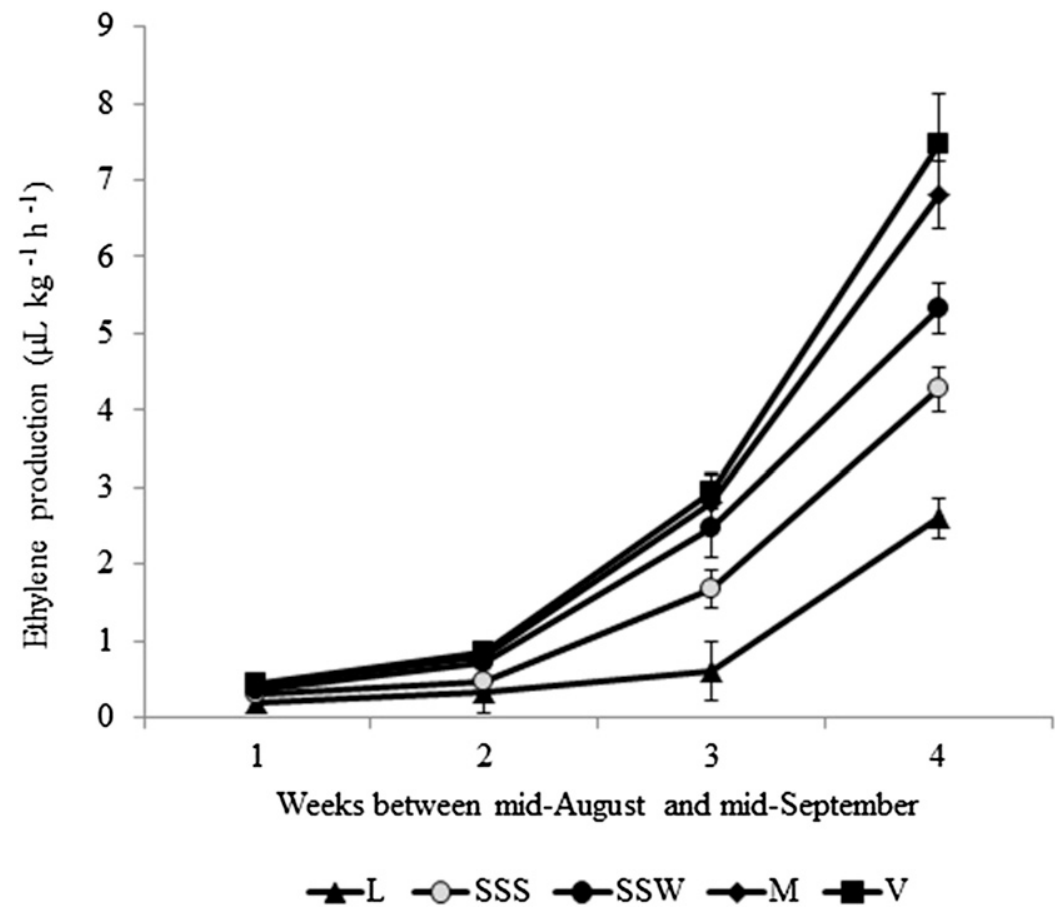

Fig. 4. Relationships between orchard floor management systems (OFMS) and fruit maturity as ethylene production, measured weekly during Aug. to Sept. 2010 as an example $(n=80)$. L = living mulch; SSW = sandwich system during whole year; SSS = sandwich system during the season; $\mathrm{M}=$ mechanical cultivation; $\mathrm{V}=$ vinegar treatment. Bars represent confidence interval between OFMS at $P \leq 0.05$ according to Tukey's test. improving soil quality, and high yield of quality fruit. This integration was investigated in the present by replacing intensive mechanical weed control with four different OFMS: acetic acid, L, and two sandwich systems.

As expected, M led to effective weed control during the three seasons without negative effects on either tree growth or fruit yield, as reported previously by Hogue and Neilsen (1987). However, the M treatment resulted in small fruits, perhaps as a result of high fruit set. Large canopy size in M plots decreased light intensity and fruit calcium content, resulting in poor storage potential. Hoagland et al. (2008) reported that tillage had negative impacts on soil quality and our results showed that tillage decreased soil respiration, perhaps as a result of mechanical effects on soil structure.

Acetic acid (V) applied at a rate of 3060 $\mathrm{L} \cdot \mathrm{ha}^{-1}$ showed very good weed suppression in comparison with tillage, although a relatively low concentration ( $12 \%$ ) was used. In a previous study, a concentration of no less than $20 \%$ was recommended as the minimum active level (Barker and Prostak, 2009). Early application of the acid on non-rainy days might result in good absorption by the weed leaves, resulting in cell membrane dissolution and plant death. In an earlier study, we found that the activity of acetic acid against weeds depends more on dose $\left(\mathrm{L} \cdot \mathrm{ha}^{-1}\right)$ than on concentration of the spraying solution (Hansson, 1994). Acetic acid application did not improve tree growth, apple yield, yield efficiency, or fruit quality in comparison with mechanical weed control, perhaps because these two systems had similar effects on tree nutrition and light intensity. It has been reported previously that acetic acid as a non-selective contact herbicide does not cause any tree damage or decreased soil $\mathrm{pH}$ (Delate et al., 2005). Other studies suggest that application of acetic acid must be repeated three times to control perennial species (Young, 2004) and cannot completely replace tillage (Markhart et al., 2005). By spraying tree strips with acetic acid and cultivating the soil outside the strips, weeds near the trunk could be removed without any damage to the trunk, whereas the tillage could be performed faster using simpler equipment.

Competitive interactions between apple trees and vegetative cover in the tree rows are one of the main factors influencing tree growth and yield. Applying a sandwich system during the growing season (SSS treatment) showed improved but not sufficient weed suppression compared with $\mathrm{M}$. Clear competition between tree and surface vegetation in both L and SSS plots was noted, impairing tree nutrition. Similar results have been reported by Stefanelli et al. (2009). The two systems reduced apple yield, yield efficiency, and TCSA not only during orchard establishment as was reported previously (Atucha et al., 2011), but also in mature orchards. Neilsen and Neilsen (2003) concluded that the $\mathrm{N}$ requirement for an apple 
Table 6. Effects of different orchard floor management systems (OFMS) on fruit mineral content and fruit storage potential, estimated as fungal decay occurrence during 4 months in a controlled atmosphere $\left(2.0 \mathrm{kPa} \mathrm{O}_{2}\right.$ and $2.0 \mathrm{kPa} \mathrm{CO}$ ).

\begin{tabular}{lcccccc}
\hline & \multicolumn{2}{c}{${\mathrm{K}: \mathrm{Ca}^{-1}}$ in fruit at harvest } & & \multicolumn{3}{c}{ Fungal decay during storage (\%) } \\
\cline { 2 - 3 } \cline { 5 - 7 } OFMS $^{\mathrm{z}}$ & 2009 & 2010 & & 2008 & 2009 & 2010 \\
\hline $\mathrm{M}$ & $37.0 \mathrm{a}^{\mathrm{y}}$ & $48.0 \mathrm{a}$ & & $6.4 \mathrm{a}$ & $4.3 \mathrm{a}$ & $5.8 \mathrm{a}$ \\
$\mathrm{V}$ & $32.0 \mathrm{a}$ & $41.0 \mathrm{a}$ & & $3.3 \mathrm{~b}$ & $3.8 \mathrm{a}$ & $3.8 \mathrm{~b}$ \\
$\mathrm{~L}$ & $25.0 \mathrm{~b}$ & $28.0 \mathrm{bc}$ & & $4.5 \mathrm{ab}$ & $2.3 \mathrm{a}$ & $3.8 \mathrm{~b}$ \\
$\mathrm{SSS}$ & $24.0 \mathrm{~b}$ & $32.0 \mathrm{~b}$ & & $4.8 \mathrm{ab}$ & $4.8 \mathrm{a}$ & $3.8 \mathrm{~b}$ \\
$\mathrm{SSW}$ & $18.0 \mathrm{c}$ & $20.0 \mathrm{c}$ & & $3.3 \mathrm{~b}$ & $4.9 \mathrm{a}$ & $3.6 \mathrm{~b}$ \\
\hline
\end{tabular}

${ }^{\mathrm{z}}$ OFMS $=$ orchard floor management systems; $\mathrm{M}=$ mechanical cultivation; $\mathrm{V}=$ vinegar treatment; $\mathrm{L}=$ living mulch; $\mathrm{SSS}=$ sandwich system during the season; SSW = sandwich system during whole year.

yalues followed by the same letter are not statistically different at $P \leq 0.05$ according to Tukey's test. $\mathrm{K}: \mathrm{Ca}=$ potassium:calcium ratio.

Table 7. Effects of different orchard floor management systems (OFMS) on fruit storage potential, estimated as changes in fruit quality during 4 months in a controlled atmosphere $\left(2.0 \mathrm{kPa} \mathrm{O}_{2}\right.$ and 2.0 $\mathrm{kPa} \mathrm{CO} 2)$ and after 1 week as shelf life $\left(18 \pm 2{ }^{\circ} \mathrm{C}\right.$ and $80 \%$ relative humidity).

\begin{tabular}{|c|c|c|c|c|c|c|c|c|c|}
\hline \multirow[b]{3}{*}{ OFMS $^{z}$} & \multicolumn{8}{|c|}{ A. Post-storage } & \\
\hline & \multicolumn{3}{|c|}{ Firmness decline (\%) } & \multicolumn{3}{|c|}{$\mathrm{TA}^{\mathrm{y}}$ decline $(\%)$} & \multicolumn{3}{|c|}{ Taste $\left(\mathrm{SSC}: \mathrm{TA}^{-1}\right)$ decline $(\%)$} \\
\hline & 2008 & 2009 & 2010 & 2008 & 2009 & 2010 & 2008 & 2009 & 2010 \\
\hline$\overline{\mathrm{M}}$ & $27.7 a^{x}$ & $20.3 \mathrm{~b}$ & $21.0 \mathrm{a}$ & $72.3 \mathrm{a}$ & $53.4 \mathrm{a}$ & $54.3 \mathrm{a}$ & $55.3 \mathrm{a}$ & $26.1 \mathrm{a}$ & $26.9 \mathrm{a}$ \\
\hline V & $26.9 \mathrm{a}$ & $23.6 \mathrm{~b}$ & 18 & & $\mathrm{a}$ & & $24.2 \mathrm{~b}$ & $25.5 \mathrm{a}$ & $23.4 \mathrm{~b}$ \\
\hline $\mathrm{L}$ & $7 \mathrm{a}$ & a & 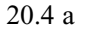 & b & 50.7 & & b & $8.0 \mathrm{a}$ & $27.3 \mathrm{a}$ \\
\hline SS & $6 \mathrm{~b}$ & $\mathrm{a}$ & $\mathrm{a}$ & $50.6 \mathrm{~b}$ & 50 & a & 6. & $26.4 \mathrm{a}$ & $27.4 \mathrm{a}$ \\
\hline SS & $21.3 \mathrm{~b}$ & $16.0 \mathrm{c}$ & $20.0 \mathrm{a}$ & $21.3 \mathrm{c}$ & $50.0 \mathrm{a}$ & $37.0 \mathrm{~b}$ & $15.3 \mathrm{c}$ & $27.0 \mathrm{a}$ & $17.1 \mathrm{c}$ \\
\hline \multirow[t]{3}{*}{$P \leq 0.05$} & 0.049 & 0.047 & 0.331 & 0.000 & 0.475 & 0.000 & 0.000 & 0.246 & 0.000 \\
\hline & \multicolumn{6}{|c|}{ B. After shelf life } & & & \\
\hline & \multicolumn{3}{|c|}{ Firmness decline (\%) } & \multicolumn{3}{|c|}{$\mathrm{TA}^{\mathrm{y}}$ decline $(\%)$} & \multicolumn{3}{|c|}{ Taste $\left(\mathrm{SSC}_{\mathrm{TA}}{ }^{-1}\right)$ decline $(\%)$} \\
\hline OFM & 2008 & 2009 & 2010 & 2008 & 2009 & 2010 & 2008 & 2009 & 2010 \\
\hline$\overline{\mathrm{M}}$ & $20.4 \mathrm{a}^{\mathrm{x}}$ & $27.5 \mathrm{a}$ & $28.3 \mathrm{a}$ & $25.0 \mathrm{a}$ & $19.0 \mathrm{a}$ & $20.0 \mathrm{a}$ & $17.8 \mathrm{~b}$ & $19.3 \mathrm{a}$ & $17.0 \mathrm{a}$ \\
\hline $\mathrm{V}$ & $23.8 \mathrm{a}$ & $24.5 \mathrm{ab}$ & $18.8 \mathrm{~b}$ & $19.3 \mathrm{ab}$ & $17.0 \mathrm{a}$ & $12.3 \mathrm{~b}$ & $23.8 \mathrm{a}$ & $21.8 \mathrm{a}$ & $16.3 \mathrm{a}$ \\
\hline $\mathrm{L}$ & $3 \mathrm{a}$ & $16.5 \mathrm{c}$ & $18.0 \mathrm{~b}$ & $11.5 \mathrm{c}$ & $6.5 \mathrm{c}$ & & $12.8 \mathrm{c}$ & $13.8 \mathrm{~b}$ & $12.5 \mathrm{c}$ \\
\hline & $3 a$ & $17.5 \mathrm{c}$ & $17.3 \mathrm{~b}$ & $15.5 \mathrm{bc}$ & $13.3 \mathrm{~b}$ & $13.5 \mathrm{~b}$ & $13.3 \mathrm{c}$ & $18.5 \mathrm{a}$ & $13.5 \mathrm{~b}$ \\
\hline & $18.8 \mathrm{a}$ & $18.5 \mathrm{bc}$ & $17.8 \mathrm{~b}$ & $14.5 \mathrm{bc}$ & $7.3 \mathrm{c}$ & $8.3 \mathrm{bc}$ & $12.3 \mathrm{c}$ & $12.0 \mathrm{~b}$ & $11.5 \mathrm{c}$ \\
\hline$=0.05$ & 0.061 & 0.000 & 0.000 & 0.000 & 0.000 & 0.000 & 0.000 & 0.001 & 0.002 \\
\hline
\end{tabular}

${ }^{\mathrm{z}} \mathrm{OFMS}=$ orchard floor management systems; $\mathrm{M}=$ mechanical cultivation; $\mathrm{V}=$ vinegar treatment; $\mathrm{L}=$ living mulch; SSS = sandwich system during the season; SSW = sandwich system during whole year.

${ }^{\mathrm{y}} \mathrm{TA}=$ titratable acidity; $\mathrm{SSC}=$ soluble solids content.

${ }^{x}$ Values followed by the same letter are not statistically different at $P \leq 0.05$ according to Tukey's test.

orchard ranges between 20 and $35 \mathrm{~kg} \cdot \mathrm{ha}^{-1}$. In the present study, the soil $\mathrm{N}$ content in 2009 exceeded this level, irrespective of OFMS treatment, and a weak correlation was found between soil $\mathrm{N}$ content and yield (Pearson: $r=0.43$ ). Although L and SSS did not decrease soil $\mathrm{N}$ content below the minimum suggested level in the 2010 season, they caused lower yield and tree growth. A strong correlation between soil $\mathrm{N}$ and yield was observed (Pearson: $r=0.92$ ). Increasing the $\mathrm{N}$ supply by $10 \%$ was not enough to overcome the competition in SSS plots, perhaps because this level was still low because grass is a stronger competitor for $\mathrm{N}$ and recycles more $\mathrm{N}$ than apple trees (Yao et al., 2005). In addition, low leaf $\mathrm{N}$ content in the L and SSS plots could not be modified by returning cover crop clippings to the tree row. Similar results were obtained by Sanchez et al. (2007). However, increasing the N supply and distribution of cover crop clippings to the tree position may decrease this negative effect. On the other hand, the L and SSS treatments improved soil respiration and light intensity (possibly as a result of weak tree vigor) and increased leaf and fruit $\mathrm{Ca}$ content and $\mathrm{Ca}: \mathrm{K}$ ratio, resulting in good fruit quality and storability (Blanke, 2008).
The sandwich system during the whole year (SSW) resulted in lower weed cover compared with L and SSS, but not V and M. It could be a good compromise with improved soil quality and tree growth, because it increased soil respiration and leaf and fruit calcium content with a moderate $\mathrm{N}$ reduction. Trees grown with various groundcover management systems generally have deeper roots and lower root density compared with trees grown in bare soil (Yao et al., 2005). The SSW treatment presumably had multiple effects on the tree root system. It decreased root density and avoided root damage resulting from tillage, resulting in an acceptable tree size, whereas light intensity and fruit growth and quality were improved without negative effects on yield. Fruit also showed lower fungal decay, less softening, lower acidity deterioration, and less color decline, resulting in good storability. These results confirm previous claims that elimination of surface vegetation year-round may be unnecessary because of its impacts on soil conditions (Oliveira and Merwin, 2001). It may also damage the new roots, especially after harvesting.

A weed-free period during June to August provided the best tree growth and the highest apple yield. The effect of this weed-free period was more important than a late summer weed-free period. These results are compatible with previous findings that tree performance depends on weed-free time more than weed-free area (Merwin and Ray, 1997). Suppressing surface vegetation during the entire growing season improves tree productivity (Tesic et al., 2007). Weed elimination between harvest and leaf fall had no clear effect on tree growth and yield in this study, as also found by Roper et al. (1988).

Tree row management had a strong impact on the development of weed communities in the present study. Plots of different OFMS contained various weed species, whereas L, SSS, and SSW had more species. Voles (Microtus sp.) were not observed to be a problem in this work.

Some more studies are needed before the SSW strategy can be fully recommended as an alternative to mechanical weed control in organic orchards. Such studies should examine, e.g., establishment of non-competitive species of $\mathrm{L}$, the relationship with pest protection, rootstock vigor, and carbon:nitrogen ratio in the soil under the SSW system.

\section{Conclusions}

A comparison of various orchard floor management strategies (acetic acid, L, and two sandwich systems) and a standard mechanical cultivation technique showed that a sandwich system during the whole year (SSW) eliminated vegetative cover competition, increased soil respiration, improved leaf and fruit $\mathrm{Ca}$ content and resulted in moderate leaf and fruit $\mathrm{N}$ content and tree growth reduction. Apples from SSW trees had good quality and high storability. Having a sandwich system during the summer (SSS) also decreased weeds, increased soil respiration, and improved fruit quality, but it decreased apple yield and required additional $\mathrm{N}$. The SSW strategy can be a useful alternative to mechanical cultivation if weak vegetation is established in narrow strips under the tree rows and $\mathrm{N}$ in the soil is continually adjusted during the season. Control of weed cover from late May to mid-July in all OFMS tested had a higher influence on apple yield and fruit quality than weed control in late summer and early fall.

\section{Literature Cited}

Alef, K. 1998. Soil respiration, p. 217-224. In: Alef, K. and P. Nanniperi (eds.). Methods in applied soil microbiology and biochemistry. Academic Press, New York, NY.

Atucha, A., I. Merwin, and M. Brown. 2011. Longterm effects of four groundcover management systems in an apple orchard. HortScience 46:1176-1183.

Atucha, A., I.A. Merwin, M.G. Brown, F. Gardiazabal, F. Mena, C. Adriazola, M. Goebel, and T. Bauerle. 2013. Root distribution and demography in an avocado (Persea americana) orchard under groundcover management systems. Funct. Plant Biol. 40:507-515.

Barker, A.V. and R.G. Prostak. 2009. Alternative management of roadside vegetation. HortTechnology 19:346-352. 
Blanke, M. 2008. Alternatives to reflective mulch cloth $\left(\right.$ Extenday $\left.^{\mathrm{TM}}\right)$ for apple under hail net? Sci. Hort. 116:223-226.

Camelo, L. and P. Gomez. 2004. Comparison of color indexes for tomato ripening. Horticultura Brasileira, Brasília 22:534-537.

Cockroft, B. and J. Wallbrink. 1996. Root distribution of orchard trees. Austral. J. Agr. Res. 17:49-54.

Delate, K., A. McKern, and M. Kirkland. 2005. Weed management in organic grapes. HortScience 40:1068.

Delate, K., A. McKern, R. Turnbull, J.T. Walker, R. Volz, A. White, V. Bus, D. Rogers, L. Cole, N. How, S. Guernsey, and J. Johnston. 2008. Organic apple systems: Constraints and opportunities for producers in local and global markets: Introduction to the colloquium. HortScience 43:6-11.

Glover, J., J. Reganold, and P. Andrews. 1999. Systematic method for rating soil quality of conventional, organic, and integrated apple orchards in Washington State. Agr. Ecosyst. Environ. 80:29-45.

Goh, K. and G. Ridgen. 1995. Understory biomass production and biological nitrogen fixation in an organic apple orchard in Canterbury, New Zealand. Commun. Soil Sci. Plant Anal. 26:3261-3273.

Granatstein, D. 2003. Organic tree fruit research needs for Washington state. Center for Sustaining Agriculture and Natural Resources, Washington State University, Wenatchee, WA. 24 Apr. 2007. <http://organic.tfrec.wsu.edu/OrganicIFP/ OrganicFruitProduction/Organic $\% 20 \mathrm{TF} \% 20$ Research\%20Summary\%20Sept03.pdf>.

Granatstein, D. and K. Mullinix. 2008. Mulching options for Northwest organic and conventional orchards. HortScience 43:45-50.

Hansson, D. 1994. Acetic acid and Foraform (ammoniumtetraformiate) for weed control. Swedish University of Agricultural Sciences. Rapport 179. Alnarp. ISSN 0283-0086, ISRN SLU-LT-R-179-SE.

Hansson, D. and J. Ascard. 2002. Influence of developmental stage and time of assessment on hot water weed control. Weed Research Oxford 42:307-316.

Hoagland, L., L. Carpenter-Boggs, D. Granatstein, M. Mazzola, J. Smith, F. Peryea, and J. Reganold. 2008. Orchard floor management effects on nitrogen fertility and soil biological activity in a newly established organic apple orchard. Biol. Fertil. Soils 45:11-18.

Hogue, E. and G. Neilsen. 1987. Orchard floor vegetation management. Hort. Rev. 9:377-430.

Johnson, E., T. Wolf, B. Caldwell, R. Barbour, R. Holm, and K. Sapsford. 2004. Efficacy of vinegar (acetic acid) as an organic herbicide. Agriculture Development Fund (ADF) Project No. 20020202 and Agriculture and Agri-Food Canada (AAFC) Project A03637, Final report. University of Saskatchewan, Saskatoon. 15 Oct. 2008. <http://www.agr.gov.sk.ca/apps/adf/adf admin/reports/20020202.pdf $>$.

Jordbruksverket. 2014. 23 Sept. 2014. <http:// webbutiken.jordbruksverket.se/sv/artiklar/ ovr228.html>.

Markhart, A., M. Harr, and P. Burkhouse. 2005. Weed control in organic vegetable production:
The use of sweet corn transplants and vinegar. HortScience 40:1093.

Marsh, K., M. Daly, and T. McCarthy. 1996. The effect of understory management on soil fertility, tree nutrition, fruit production and apple fruit quality. Biol. Agr. Hort. 13:161-173.

Melander, B. 1997. Optimization of the adjustment of a vertical axis rotary brush weeder for intrarow weed control in row crops. J. Agr. Eng. Res. 68:39-50.

Merwin, I. 2003. Orchard-floor management systems. In: Ferree, D.C. and I.J. Warrington (eds.). Apple-Botany, production and uses.

Merwin, I., D. Rosenberger, C. Engle, D. Rist, and M. Fargione. 1995. Comparing mulches, herbicides, and cultivation as orchard groundcover management systems. HortTechnology 5:151158.

Merwin, I. and J. Ray. 1997. Spatial and temporal factors in weed interference with newly planted apple trees. HortScience 32:633-637.

Merwin, I., J. Ray, and P. Curtis. 1999. Orchard groundcover management systems affect meadow vole populations and damage to apple trees. HortScience 34:271-274.

Merwin, I. and W. Stiles. 1994. Orchard ground cover management impacts on apple tree growth and yield, and nutrient availability and uptake. J. Amer. Soc. Hort. Sci. 119:209-215.

Merwin, I., W. Stiles, and H. van Es. 1994. Orchard groundcover management impacts on soil physical properties. J. Amer. Soc. Hort. Sci. 119:216-222.

Neilsen, G. and D. Neilsen. 2003. Nutritional requirements of apple, p. 267-302. In: Ferree, D.C. and I.J. Warrington (eds.). Apples: Botany, production, and uses. CABI Publ., Cambridge, UK.

Oliveira, M.T. and I.A. Merwin. 2001. Soil physical conditions in a New York orchard after eight years under different groundcover management systems. Plant Soil 234:233-237.

Page, A.L., R.H. Miller, and D.R. Keeney. 1982. Methods of soil analysis. Part 2. 2nd Ed. American Society of Agronomy and Soil Science Society of America, Madison, WI.

Roper, T.R., J.D. Keller, W.H. Loescher, and C.R. Rom. 1988. Photosynthesis and carbohydrate partitioning in sweet cherry: Fruiting effects. Physiol. Plant. 72:42-47.

Sanchez, E.E., A. Giayetto, L. Cichon, D. Fernandez, M.C. Aruani, and M. Curetti. 2007. Cover crops influence soil properties and tree performance in an organic apple (Malus domestica Borkh) orchard in northern Patagonia. Plant Soil 292:193203.

Sanchez, J., C. Edson, G. Bird, M. Whalon, T. Willson, R. Harwood, K. Kizilkaya, J. Nugent, W. Klein, A. Middleton, T. Loudon, D. Mutch, and J. Scrimger. 2003. Orchard floor and nitrogen management influences soil and water quality and tart cherry yields. J. Amer. Soc. Hort. Sci. 128:277-284.

Sandskär, B. 2005. Pests in fruit (Skadegörare i frukt). The Swedish Board of Agriculture (SJV), Jönköping, Sweden.

SANCO. 2013. Final review: Report for the active substance acetic acid. Rev. 4, /2602/08, 6 July 2013.
Schmid, A. and F. Weibel. 2000. Das SandwichSystem-ein Verfahren zur herbizidfreien Baumstreifenbe- wirtschaftung? [The Sandwich System, a procedure for herbicide free in-row weed control?]. Obstbau 25:214-217.

Stefanelli, D., R. Zoppolo, R. Perry, and F. Weibel. 2009. Organic orchard floor management systems for apple effect on rootstock performance in the midwestern United States. HortScience 44:263-267.

Stork, P. and P. Jerie. 2003. Initial studies of the growth, nitrogen sequestering, and dewatering potential of perennial grass selections for use as nitrogen catch crops in orchards. Austral. J. Agr. Res. 54:27-37.

Tahir, I. 2006. Prediction of optimum harvesting date for some apple cultivars, p. 1-10. In: Control of pre- and postharvest factors to improve apple quality and storability. Diss. SLU.

Tahir, I., E. Johansson, and M.E. Olsson. 2005. Groundcover materials improve quality and storability of 'Aroma' apples. HortScience 40:1416-1420.

TerAvest, D., J. Smith, L. Carpenter-Boggs, L. Hoagland, D. Granatstein, and J.P. Reganold. 2010. Influence of orchard floor management and compost application timing on nitrogen partitioning in apple trees. HortScience 45:637-642.

Tesic, D., M. Keller, and R.J. Hutton. 2007. Influence of vineyard floor management practices on grapevine vegetative growth, yield, and fruit composition. Amer. J. Enol. Viticult. 58:1-11.

Varela, P., A. Salvador, and S. Fiszman. 2005. Shelf-life estimation of 'Fuji' apples: Sensory characteristics and consumer acceptability. Postharvest Biol. Technol. 38:18-24.

Weibel, F. and A. Häseli. 2003. Organic apple production-With emphasis on European systems. In: Ferree, D.C. and I.J. Warrington (eds.). The CABI apple book. CABI Publishing, Wallingford, Oxon, UK.

Weibel, F., L. Tamm, E. Wyss, C. Daniel, A Häseli, and F. Suter. 2007. Organic fruit production in Europe: Successes in production and marketing in the last decade, perspectives and challenges for the future development. Acta Hort. 737:163-172.

Weidenfeld, B., L.B. Fenn, S. Miyamoto, D. Swietlik, and C. Marlene. 1999. Using sod to manage nitrogen in orchard floors. Commun. Soil Sci. Plant Anal. 30:353-363.

Wooldridge, J. and R. Harris. 1991. Effect of organic mulches and plastic sheet on soil temperature. Deciduous Fruit Grower 41:118121 .

Yao, S., I. Merwin, G. Bird, G. Abawi, and J. Thies. 2005. Orchard floor management practices that maintain vegetative or biomass groundcover stimulate soil microbial activity and alter soil microbial community composition. Plant Soil 271:377-389.

Young, S.L. 2004. Natural products for control of annual vegetation along road-sides. Weed Technol. 18:580-587.

Zoppolo, R.J., D. Stefanelli, G.W. Bird, and R.L. Perry. 2011. Soil properties under different orchard floor management systems for organic apple production. Org. Agr. 1:231-246. 